\title{
Australian Journal of \\ Physiological, biochemical and nutritional changes in soybean in response to application of steel slag
}

\author{
Alessandra Vieira da Silva ${ }^{1 *}$, Angélica Cristina Fernandes Deus ${ }^{1}$, Mara Lúcia Cruz de Souza ${ }^{2}$, Fernando \\ Broetto $^{2}$, Leonardo Theodoro Büll ${ }^{1}$
}

\author{
'Department of Soil and Environmental Resources, College of Agronomic Sciences, São Paulo State University \\ (Unesp), Botucatu, São Paulo State, Brazil \\ ${ }^{2}$ Rural Engineering Department, College of Agronomic Sciences, São Paulo State University (Unesp), Botucatu, São \\ Paulo State, Brazil
}

\section{*Corresponding author: alessandrav.silvaa@gmail.com}

\begin{abstract}
Steel slag is a powdery industrial residue that has $\mathrm{CaO}, \mathrm{MgO}$ and $\mathrm{SiO}_{2}$ in its composition, which enables its use in agriculture for soil acidity correction. Most studies involving this residue have focused on understanding its effects on the soil, not always considering its action on the plant metabolism. Thus, the present study aimed to evaluate physiological, biochemical and nutritional changes in soybean plants due to application of lime and steel slag on the soil surface or by incorporation. The experiment was carried out in the field, with six soil acidity corrective materials: stainless steel slag, steel slag, ladle slag, wollastonite rock, dolomitic lime and calcined dolomite, plus a negative control, which did not receive correctives. Two application methods were adopted: soil surface application or incorporation. Sixty days after application, the soybean crop was established. Soybean response changed with the application method, since incorporation of corrective materials provided greater production of fresh and dry leaf mass and stem fresh mass, increased chlorophyll b and leaf $\mathrm{K}$ levels, and contributed to a greater number of plants per hectare and pods per plant, compared to surface application. Besides such benefits, there was no difference between the effect of application methods on soybean yield, indicating that both incorporation and surface application are efficient in increasing soybean grain yield. The correctives steel slag, wollastonite and calcined dolomite provided significant increases in soybean yield.
\end{abstract}

Keywords: Soil acidity. Liming. Slags. Silicate. Glycine max.

Abbreviations: CEC_Cation Exchange Capacity; ROS_ Reactive Oxygen Species; Fe_Iron; Mn_ Manganese; Al_ Aluminum; DSW_ Dry Stem Weight; SS_ Steel Slag; W_ Wollastonite; $C_{-}$Control; LS_Ladle Slag; SSS_ Stainless Steel Slag; CDL_Calcined Dolomitic Lime and DL_ Dolomitic Lime. S_ Superficial Application; I_ Incorporation. BS_ Base Saturation. K_ Potassium; N_ Nitrogen; P_ Phosphorus; Ca_Calcium; Mg_ Magnesium; S_ Sulfur; TSP_ Total Soluble Proteins; POD_Peroxidase; CAT_Catalase; SOD_ Superoxide Dismutase; SRA_ Antioxidative System; LA_ Leaf Area; FLW_ Fresh Leaf Weight; DLW_ Dry Leaf Weight; FSW_Fresh Stem Weight; DSW_Dry Stem Weight; Si_Silicon.

\section{Introduction}

Soybean (Glycine max) is the crop of highest productive expression in Brazil. In the 2019 harvest, the area and volume of soybean production corresponded to approximately $48 \%$ of the 240.65 million tons of grains produced in the country (Conab, 2019). Most soybean cultivation involves no-till system (Pauletti et al, 2014) and liming (Lopes et al, 1991)

Brazilian soils have several limiting attributes for the crop yield, including acidity, toxic elements ( $\mathrm{Al}$ and $\mathrm{Mn}$ ), and low cation exchange capacity (CEC) (Gama et al., 2007). Liming is frequently used to neutralize the soil acidity, reduce the acidity effect on plant development, improve the microorganism activity, reduce the abiotic stress, and increase the nutrient availability (Martins et al, 2017). Lime is the most used corrective material; however, residues from the metallurgical industries such as steel slags can also be successfully employed in agricultural activity (Deus et al., 2019).
Steel slags are $\mathrm{Ca}$ and $\mathrm{Mg}$ silicates containing $\mathrm{CaO}, \mathrm{MgO}$, $\mathrm{SiO}_{2}, \mathrm{P}_{2} \mathrm{O}_{5}, \mathrm{FeO}$ and $\mathrm{MnO}$ in their composition. Their chemical and physical constitution may vary due to the different processes and different raw materials used in metallurgical industries (Deus et al., 2019). Steel slags can be adopted to correct soil acidity; increase $\mathrm{pH}$ levels, exchangeable calcium, exchangeable magnesium, CEC, and soil base saturation; improve phosphorus and silicon availability, and reduce $\mathrm{Fe}, \mathrm{Mn}$ and Al toxicity (Pulz et al., 2008). It must also be emphasized that the use of steel slag in agriculture is a viable alternative for the final disposal of this such material since its waste is inappropriately discarded in landfills and improper places.

Some studies have shown that steel slags efficiently replace lime in soil acidity correction since they dissolve and make elements available to the plants more rapidly and at greater depths (Corrêa et al., 2009; DEUS et al., 2019).

Another advantage of slag application is Si supply to the crop. Silicon has been evidenced to have an indirect effect on the productivity of soybean crops by improving the plant 
architecture and the leaf arrangement, which makes the plants stronger and more resistant to lodging (Agarie et al., 1998).

Plants may alter their metabolism when exposed to inadequate environmental conditions and abiotic stress. Excess elements in the soil, such as manganese, may induce abnormal metabolic events that can lead to the production of reactive oxygen species (ROS) (Amaro et al., 2018). Unless ROSs are neutralized, they may affect the cell structure and cause cellular death. Oxidative damage to the plant cell structures creates an imbalance between antioxidant activity and ROS production, which activates enzymes like superoxide dismutase (SOD), peroxidase (POD) and catalase (CAT) (Qi et al, 2018).

Therefore, better understanding how different types of slag can be used to correct the soil acidity and improve the plant development is important. Steel slag is suggested to alter the capacity of plants to respond to metabolic changes caused by biotic and abiotic factors. Thus, the aim of the present study was to evaluate physiological, biochemical and nutritional changes in soybean plants due to surface application or incorporation of lime and steel slags.

\section{Results}

\section{Soybean physiological and nutritional characteristics}

The application method influenced Fresh Leaf Weight (FLW), Fresh Stem Weight (FSW), Electrolyte Loss (EL) and Chlorophyll b (Table 3). Incorporation of acidity correctives led to greater FSW and FLW than surface application. Similarly, the highest EL and chlorophyll $b$ levels were found when the correctives were incorporated into the soil.

The tested corrective materials had an effect on Dry Leaf Weight (DLW) and Chlorophyll b (Table 3). Stainless steel slag significantly influenced DLW, compared to control, while the remaining treatments had no significant differences. The lowest Dry Stem Weight (DSW) was obtained with the control treatment. Chlorophyll $b$ levels ranged from $16.0 \mu \mathrm{g} \mathrm{cm}^{-2}$ for the control to $23.8 \mu \mathrm{g} \mathrm{cm}^{-2}$ for wollastonite; however, there was no significant difference between the studied correctives.

The nutrients $K$ and $B$ were also influenced by the application method, since $K$ level was higher with the incorporation of correctives while $B$ level was higher with surface application. Considering the soil acidity correctives, there was also a significant effect on the leaf levels of $\mathrm{Ca}$, $\mathrm{Mg}, \mathrm{Fe}, \mathrm{Mn}$, and $\mathrm{Zn}$ (Table 4).

Higher levels of the nutrient $\mathrm{Ca}$ were provided by the correctives SS, W and SSS, which were similar to each other, whereas limestones did not differ from control (Table 4). Mg levels obtained with DL were higher than those found with SS and W and similar to those resulting from control, LS, SSS and CDL application.

Fe level obtained with the control treatment was superior to that found with LS and $W$ and similar to the levels resulting from SS, SSS, CDL and DL, while for Mn levels, the control was superior to all other treatments. Regarding $\mathrm{Zn}$ levels, control treatment was superior to SSS and DL and similar to SS, W, LS and CDL (Table 4).

\section{Biochemical characteristics and soybean productivity}

The analyzed biochemical parameters indicated interactions between the application method and the acidity correctives considering the enzyme SOD, which is part of the plant's antioxidative response system (Tables 5 and 6). When incorporation was adopted, SOD activity was the same, regardless of the corrective material. However, for surface application, $\mathrm{W}$ and the control were similar to each other in showing higher SOD activity, compared to the other correctives.

Considering the factors separately, there was a difference between the application methods since incorporation resulted in higher number of plants per hectare and higher number of pods per plant, compared to surface application. The biochemical parameter Total Soluble Proteins (TSP) was influenced by the corrective materials, ranging from 17.7200 $\mathrm{mg} \mathrm{g}^{-1}$ for the control to $25.9400 \mathrm{mg} \mathrm{g}^{-1}$ for steel slag, which showed no difference from the other treatments.

\section{Discussion}

Application of correctives by incorporation resulted in the highest values of the parameters FLW, FSW, EL, Chlorophyll $\mathrm{b}, \mathrm{K}$ level, number of plants, and number of pods/plants, compared to surface application. This was possibly due to the improved distribution of correctives $(0-0.20 \mathrm{~m})$ provided by incorporation, also favoring soil aeration and, consequently, improving the development of the plant's root system with higher nutrient and water absorption.

Wollastonite application had the greatest effect on Chlorophyll $b$, while the remaining treatments showed no significant differences (Table 4). Chlorophyll $b$ is characterized as an accessory pigment, responsible for aiding in light absorption (Silva et al., 2014), maximizing energy absorption that effectively acts in the photochemical reactions (Gill \& Tuteja, 2010) and in the photosynthesis maintenance (Imtiaz et al., 2016).

Increased leaf $\mathrm{Ca}$ levels provided by the treatment with Wollastonite were due to the Ca percentage present in this corrective material.

Mg concentration in soybean leaves was higher with $\mathrm{DL}$, compared the other treatments. This increase is related to the composition of such material, which has higher MgO values than the other correctives (Table 2), combined with the rain that occurred during the experimental period, leading to good nutrient distribution. The leaf levels of the nutrients $\mathrm{Ca}, \mathrm{Mg}, \mathrm{N}$ and $\mathrm{P}$ remained within the adequate range for soybean, except $\mathrm{K}$, which kept below the optimal range, according to Ambrosano et al. (1997).

The higher leaf level of $B$ provided by the surface application of acidity correctives can be explained by the storage of part of the available form of this element in the superficial layer of the soil, together with organic matter (Raij et al. 1997). Leaf Fe level was higher with the control than with the other treatments.

The increased $\mathrm{Mn}$ level in soybean leaves was not within the adequate range proposed by Ambrosano for the crop: from 20 to $100 \mathrm{mg} \mathrm{kg}^{-1}$. In this study, Mn values were higher than $100 \mathrm{mg} \mathrm{kg}^{-1}$ for all treatments. According to Rosolem et al. (1992), the range from $140 \mathrm{mg} \mathrm{kg}^{-1}$ to $300 \mathrm{mg} \mathrm{kg}^{-1} \mathrm{Mn}$ in mature leaves corresponds to toxic levels for soybean crops. The highest $\mathrm{Mn}$ levels (300 mg kg ) obtained with the control treatment might have contributed to the lower number of pods per plant in the control (Table 4), compared to the other treatments, corroborating the study by Heenan \& Campbel (1980)

TSP content is regarded as a reference indicator to determine and quantify several other enzyme activities. SS, either incorporated or applied on the soil surface, was the 
Table 1. Chemical characterization of the soil before the installation of the experiment, according to the different treatments, correctives and form of application.

\begin{tabular}{|c|c|c|c|c|c|c|c|c|c|c|c|}
\hline \multirow{2}{*}{ Correctives } & \multirow{2}{*}{ Application } & \multirow{2}{*}{$\begin{array}{l}\mathrm{pH} \\
\mathrm{CaCl}_{2}\end{array}$} & \multirow{2}{*}{$\begin{array}{l}\text { O.M. } \\
\text { g/dm }\end{array}$} & \multirow{2}{*}{$\begin{array}{l}\mathrm{P}_{\text {resina }} \\
\mathrm{mg} / \mathrm{dm}^{3}\end{array}$} & $\mathrm{H}+\mathrm{Al}$ & K & $\mathrm{Ca}$ & $\mathrm{Mg}$ & SB & \multirow[t]{2}{*}{ CEC } & \multirow{2}{*}{$\begin{array}{l}\text { BS } \\
\%\end{array}$} \\
\hline & & & & & \multicolumn{5}{|c|}{ - } & & \\
\hline SS & 1 & 4.4 & 28 & 12 & 65 & 0.8 & 23 & 4 & 27 & 90 & 30 \\
\hline W & I & 4.3 & 27 & 12 & 64 & 0.6 & 24 & 4 & 28 & 92 & 31 \\
\hline LS & I & 5.0 & 26 & 36 & 38 & 0.8 & 42 & 8 & 51 & 89 & 57 \\
\hline SSS & I & 4.5 & 37 & 33 & 53 & 0.9 & 32 & 7 & 41 & 94 & 44 \\
\hline CDL & 1 & 4.5 & 32 & 10 & 52 & 0.3 & 29 & 7 & 36 & 88 & 41 \\
\hline $\mathrm{DL}$ & I & 4.9 & 33 & 31 & 44 & 0.9 & 31 & 11 & 43 & 87 & 49 \\
\hline SS & S & 4.6 & 34 & 11 & 55 & 1.1 & 35 & 5 & 41 & 96 & 43 \\
\hline W & S & 4.4 & 27 & 14 & 62 & 0.5 & 28 & 4 & 32 & 94 & 34 \\
\hline LS & $S$ & 4.7 & 32 & 15 & 48 & 0.9 & 36 & 7 & 44 & 92 & 48 \\
\hline SSS & S & 4.5 & 33 & 26 & 54 & 1.3 & 48 & 12 & 62 & 116 & 53 \\
\hline $\mathrm{CDL}$ & $S$ & 4.4 & 32 & 9 & 59 & 1.1 & 26 & 7 & 35 & 94 & 37 \\
\hline $\mathrm{DL}$ & $\mathrm{S}$ & 5.2 & 31 & 28 & 35 & 0.6 & 42 & 14 & 57 & 91 & 62 \\
\hline Medium & & 4.6 & 31 & 20 & 48 & 0.8 & 33 & 8 & 41 & 87 & 44 \\
\hline $\mathrm{C}$ & $I$ & 3.8 & 25 & 58 & 110 & 0.9 & 7 & 2 & 10 & 120 & 8 \\
\hline C & S & 4.2 & 28 & 88 & 62 & 1.3 & 22 & 5 & 28 & 90 & 31 \\
\hline
\end{tabular}

SS: Steel slag; W: Wollastonite; C: Control; LS: Ladle slag; SSS: Stainless steel slag; CDL: Calcined dolomitic lime and DL: Dolomitic lime. S: Superficial and I: Incorporated. SB: Sum of Bases. BS: Base saturation. CEC: Cation exchange capacity

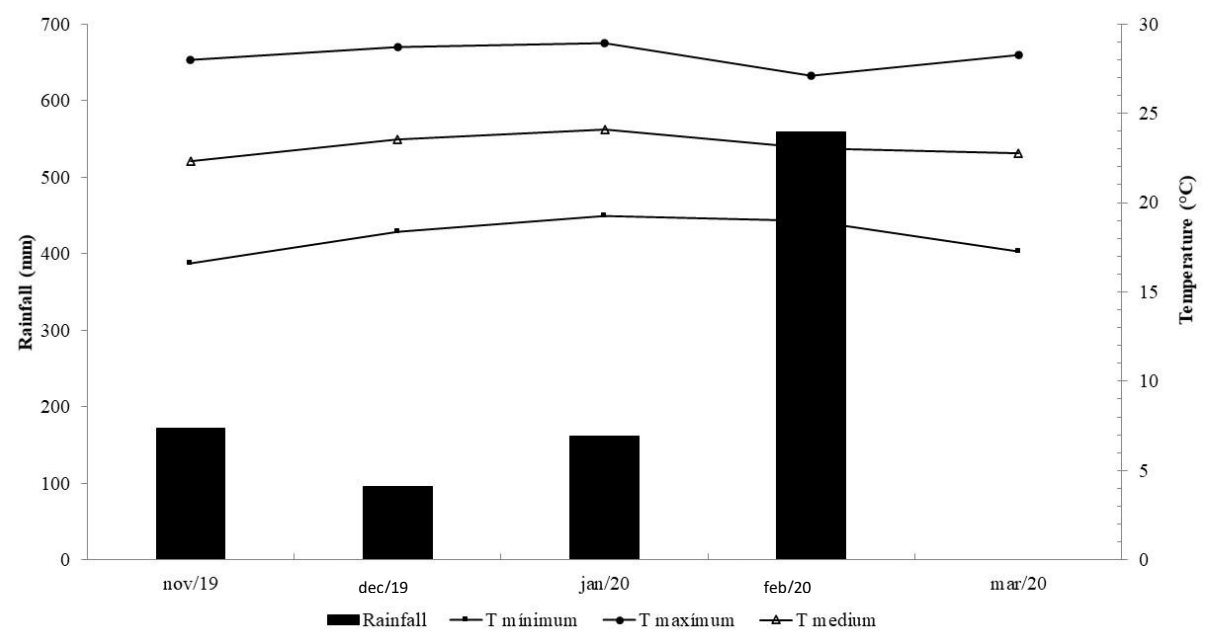

Fig 1. Monthly rainfall and maximum, medium and minimum temperature in Botucatu, State of São Paulo, Brazil during the study period, from November 2019 to March 2020.

Table 2. Chemical and physical characterization of soil acidity correctives.

\begin{tabular}{lllllll}
\hline \multirow{2}{*}{ Correctives } & \multicolumn{6}{c}{ Result in Percent \% } \\
\cline { 2 - 7 } Stainless steel slag & $\mathrm{CaO}$ & $\mathrm{MgO}$ & $\mathrm{RE}$ & $\mathrm{NP}$ & $\mathrm{PRNT}$ & Moisture \\
Steel slag & 39.67 & 11.33 & 70.97 & 86 & 61 & 2.2 \\
Calcined dolomitic lime & 35.30 & 13.10 & 73.00 & 72 & 53 & 0.9 \\
Dolomitic lime & 52.30 & 17.90 & 97.00 & 139 & 134 & 0.2 \\
Ladle slag & 31.18 & 16.29 & 89.36 & 82 & 74 & 1.9 \\
Wollastonite & 33.35 & 6.05 & 74.11 & 68 & 51 & 1.2 \\
\end{tabular}

$\mathrm{RE}=$ reactivity, expresses the corrective percentage that reacts in three months; $\mathrm{NP}=$ neutralizing power, expresses the corrective chemical potential, in CaCO $\mathrm{B}_{3}$ equivalent. 
Table 3. Leaf area (LA), leaf fresh mass (FLW), leaf dry mass (DLW), stem fresh mass (FSW), stem dry mass (DSW), leaf silicon content (Si), relative water content in leaf tissue (RWC), loss of electrolytes (EL) and pigment content: chlorophyll $a$ (Clo $a$ ), chlorophyll $b(\mathrm{Clo} b)$ and carotenoids (Car) as a function of the effect of the application mode and correctives of soil acidity on soybean cultivar TMG 7062 IPRO.

\begin{tabular}{|c|c|c|c|c|c|c|c|c|c|c|c|}
\hline Treatments & LA & FLW & DLW & FSW & DSW & $\begin{array}{l}\text { Leaf silicon } \\
\text { content }(\mathrm{Si})\end{array}$ & RWC & EL & Clo $a$ & Clo $b$ & Car \\
\hline Application (A) & $\mathrm{cm}^{2}$ plant $^{-1}$ & \multicolumn{3}{|c|}{----------- g plant -1 } & ------ & $\mathrm{mg} \mathrm{kg}^{-1}$ & $\%$ & \multicolumn{4}{|c|}{$\mu \mathrm{g} \mathrm{cm}^{2}$ of leaf } \\
\hline Incorporated & $4924.9 \mathrm{a}$ & $54.0 \mathrm{a}$ & $24.3 \mathrm{a}$ & $149.7 \mathrm{a}$ & $43.35 \mathrm{a}$ & $3.05 \mathrm{a}$ & $84.8 \mathrm{a}$ & $6.3 \mathrm{a}$ & $35.0 \mathrm{a}$ & $22.3 \mathrm{a}$ & $8.7 \mathrm{a}$ \\
\hline Superficial & $3509.1 \mathrm{a}$ & $39.7 \mathrm{~b}$ & $19.3 \mathrm{a}$ & $96.2 \mathrm{~b}$ & $43.92 \mathrm{a}$ & $2.89 \mathrm{a}$ & $88.3 \mathrm{a}$ & $5.2 \mathrm{~b}$ & $34.0 \mathrm{a}$ & $19.2 \mathrm{~b}$ & $8.5 \mathrm{a}$ \\
\hline $\mathrm{F}$ & $47.82^{\text {ns }}$ & $11.59^{*}$ & $3.73^{\mathrm{ns}}$ & $20.71 *$ & $6.37^{\mathrm{ns}}$ & $0.22^{\mathrm{ns}}$ & $3.19^{\mathrm{ns}}$ & $1.29 *$ & $1.16^{\mathrm{ns}}$ & $20.71 *$ & $6.37^{\text {ns }}$ \\
\hline \multicolumn{12}{|l|}{ Correctives (C) } \\
\hline SS & $4117.4 \mathrm{a}$ & $43.8 \mathrm{a}$ & $21.9 \mathrm{ab}$ & $126.8 \mathrm{a}$ & $43.00 \mathrm{ab}$ & $2.37 \mathrm{a}$ & $88.8 \mathrm{a}$ & $6.2 \mathrm{a}$ & $35.0 \mathrm{a}$ & $20.8 \mathrm{a}$ & $8.6 \mathrm{a}$ \\
\hline $\mathrm{W}$ & $4244.7 \mathrm{a}$ & $46.0 \mathrm{a}$ & $22.1 \mathrm{ab}$ & $120.5 \mathrm{a}$ & $44.50 \mathrm{ab}$ & $3.18 \mathrm{a}$ & $87.3 \mathrm{a}$ & $4.5 \mathrm{a}$ & $36.7 \mathrm{a}$ & $23.8 \mathrm{a}$ & $8.8 \mathrm{a}$ \\
\hline $\mathrm{C}$ & $3109.7 \mathrm{a}$ & $35.7 \mathrm{a}$ & $17.5 \mathrm{~b}$ & $88.7 \mathrm{a}$ & $49.00 \mathrm{a}$ & $3.35 \mathrm{a}$ & $89.3 \mathrm{a}$ & $5.7 \mathrm{a}$ & $30.8 \mathrm{a}$ & $16.0 \mathrm{~b}$ & $8.0 \mathrm{a}$ \\
\hline LS & $4537.5 \mathrm{a}$ & $47.6 \mathrm{a}$ & $22.5 \mathrm{ab}$ & $136.1 \mathrm{a}$ & $43.00 \mathrm{ab}$ & $2.62 \mathrm{a}$ & $83.9 \mathrm{a}$ & $6.7 \mathrm{a}$ & $35.0 \mathrm{a}$ & $21.6 \mathrm{a}$ & $8.3 \mathrm{a}$ \\
\hline SSS & $5274.4 \mathrm{a}$ & $58.2 \mathrm{a}$ & $25.6 \mathrm{a}$ & $150.1 \mathrm{a}$ & $40.62 \mathrm{~b}$ & $2.75 \mathrm{a}$ & $84.2 \mathrm{a}$ & $4.8 \mathrm{a}$ & $36.9 \mathrm{a}$ & $21.9 \mathrm{a}$ & $9.1 \mathrm{a}$ \\
\hline $\mathrm{CDL}$ & $4313.3 \mathrm{a}$ & $47.3 \mathrm{a}$ & $21.9 \mathrm{ab}$ & $124.0 \mathrm{a}$ & $45.12 \mathrm{ab}$ & $2.78 \mathrm{a}$ & $82.8 \mathrm{a}$ & $5.3 \mathrm{a}$ & $35.1 \mathrm{a}$ & $21.4 \mathrm{a}$ & $9.1 \mathrm{a}$ \\
\hline DL & $3922.0 \mathrm{a}$ & $49.1 \mathrm{a}$ & $21.1 \mathrm{ab}$ & $114.7 \mathrm{a}$ & $40.25 \mathrm{~b}$ & $2.73 \mathrm{a}$ & $88.4 \mathrm{a}$ & $7.2 \mathrm{a}$ & $34.2 \mathrm{a}$ & $20.1 \mathrm{ab}$ & $8.2 \mathrm{a}$ \\
\hline $\mathrm{F}$ & $0.28^{\mathrm{ns}}$ & $1.24^{\mathrm{ns}}$ & $2.12^{*}$ & $1.41^{\mathrm{ns}}$ & $2.52^{*}$ & $2.00^{\mathrm{ns}}$ & $0.69^{\mathrm{ns}}$ & $0.79^{\mathrm{ns}}$ & $1.19^{\mathrm{ns}}$ & $5.84 *$ & $0.74^{\mathrm{ns}}$ \\
\hline $\mathrm{A} \times \mathrm{C}$ & $2.02^{\mathrm{ns}}$ & $1.72^{\mathrm{ns}}$ & $1.82^{\mathrm{ns}}$ & $1.97^{\mathrm{ns}}$ & $2.07^{\mathrm{ns}}$ & $1.92^{\mathrm{ns}}$ & $0.39^{\mathrm{ns}}$ & $0.81^{\mathrm{ns}}$ & $0.65^{\mathrm{ns}}$ & $0.48^{\mathrm{ns}}$ & $0.64^{\mathrm{ns}}$ \\
\hline VC (\%) plot & 55 & 33 & 43 & 35 & 46 & 42 & 8 & 61 & 3 & 10 & 4 \\
\hline VC (\%) subplot & 29 & 36 & 21 & 36 & 22 & 21 & 11 & 54 & 15 & 13 & 16 \\
\hline
\end{tabular}

Averages followed by different letters in the columns differ among themselves. By the Tukey test at $5 \%\left({ }^{*}\right)$ and $1 \%\left({ }^{* *}\right)$ probability. SS - Steel slag. W - Wollastonite. C control. LS - Ladle slag. SSS - Stainless steel slag. CDL - Calcined dolomitic lime. DL - Dolomitic lime. ns - not significant.

Table 4. Average leaf contents of macronutrients ( $N, P, K, C a, M g$ and $S$ ) and micronutrients (B, Cu, Fe, Mn and $\mathrm{Zn}$ ) in soybeans, harvest $2019 / 20$ as a function of the incorporated and superficial application of acidity correction materials from soil.

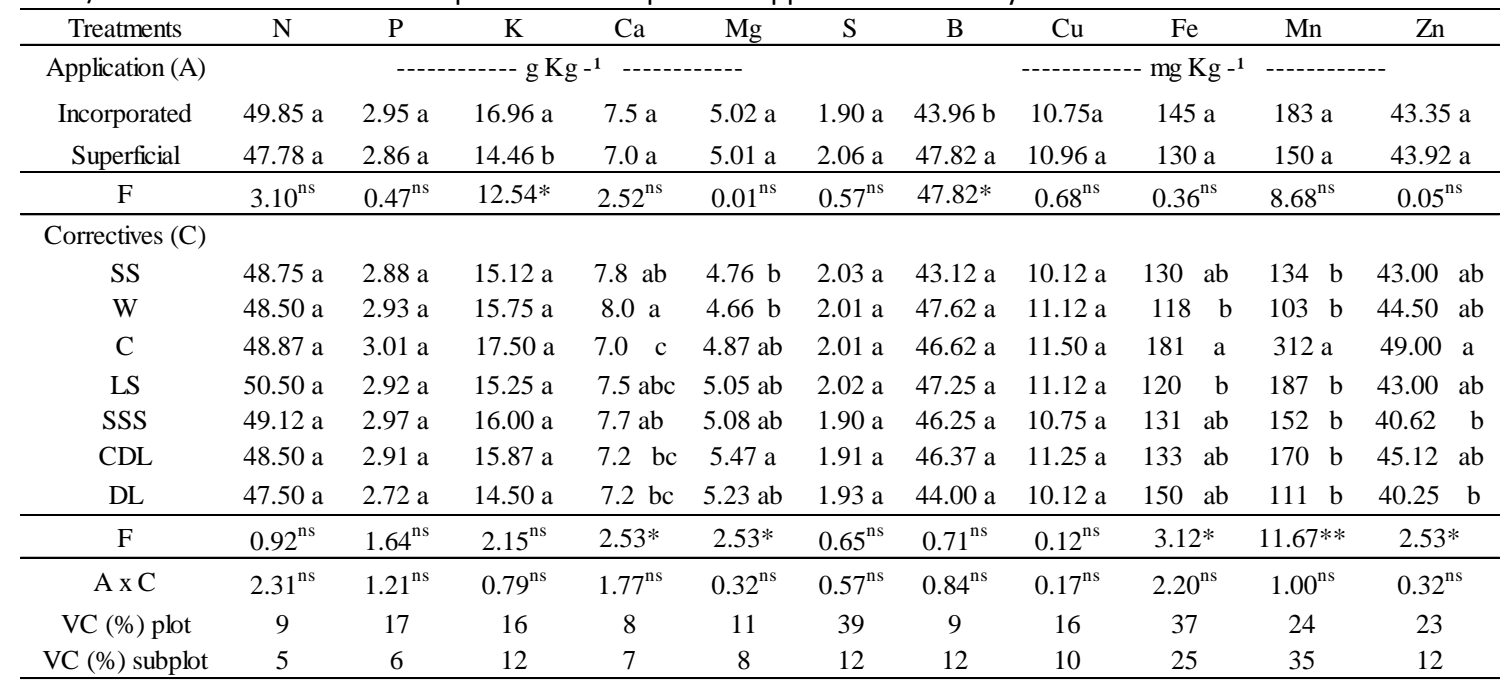

Averages followed by different letters in the columns differ among themselves. By the Tukey test at $5 \%\left({ }^{*}\right)$ and $1 \%(* *)$ probability. SS - Steel slag. W - Wollastonite. C control. LS - Ladle slag. SSS - Stainless steel slag. CDL - Calcined dolomitic lime. DL - Dolomitic lime. ns - not significant.

only treatment that had an effect on soluble proteins, probably because it provided greater protease activity, which decreased manganese toxicity for SOD in soybean leaves. Plants are capable of developing biochemical responses to survive stress; such responses are generated by an antioxidative system (SRA) and have been evaluated as stress indicators (Souza et al, 2020). In the present study, there was an increase in the activity of the enzyme SOD in response to the surface application of acidity correctives. The greater SOD activity obtained with the control treatment can be related to the excessive leaf level of manganese present in the treatment, compared to the incorporated correctives, which showed low SOD activity.
Thus, activity of other enzymes (CAT and POD) was not observed, i.e., only the enzyme that is considered the first line of the plant defense against stress was activated: SOD. However, this evidences that the plant has adapted to the environment and has not activated the other enzymes (CAT and POD) through its defense mechanism.

Critical $\mathrm{Mn}^{+2}$ levels in the leaves (below or above the adequate range) cause oxidative stress due to an increase in the concentration of hydrogen peroxide and malondialdehyde, an indicator of lipid peroxidation (Amaro et al., 2018). Such oxidative stress was evidenced by the enzyme SOD in soybean leaves. In addition, in the present study, even though $\mathrm{Mn}^{+2}$ was above the optimal level for 
Table 5. Total soluble protein content (PTS), activity of the enzymes Superoxide dismutase (SOD), Peroxidase (POD), Catalase (CAT), $\mathrm{N}^{\circ}$. of plants per hectare, $\mathrm{N}^{\circ}$. of pod / plant, $\mathrm{N}^{\circ}$. of grains / plant and productivity depending on the application and the corrective effect of soil acidity on soybean cultivar TMG 7062 IPRO.

\begin{tabular}{|c|c|c|c|c|c|c|c|c|c|}
\hline Treatments & TSP & SOD & POD & CAT & $\begin{array}{c}\text { Number of plants } \\
\text { per hectare }\end{array}$ & $\begin{array}{l}\text { Number of } \\
\text { pods/plant }\end{array}$ & $\begin{array}{l}\text { Number of } \\
\text { grains/plant }\end{array}$ & $\begin{array}{l}\text { Silicon content in } \\
\text { the grain }\end{array}$ & Yield ( $\left.\mathrm{t} \mathrm{ha}^{-1}\right)$ \\
\hline & $\left(\mathrm{mg} \mathrm{g}^{-1}\right)$ & $\left(\mathrm{UI} \mu \mathrm{g}_{\text {proteín }}{ }^{-1}\right)$ & \multicolumn{3}{|c|}{$\mu \mathrm{Kat} \mu \mathrm{g}$ proteín- 1} & \multicolumn{4}{|c|}{$\mathrm{mg} \mathrm{kg}^{-1}$} \\
\hline \multicolumn{10}{|l|}{ Application (A) } \\
\hline Incorporated & $24.3 \mathrm{a}$ & $0.98 \mathrm{a}$ & $2.7 \mathrm{a}$ & $370.4 \mathrm{a}$ & 550594 a & $78 \mathrm{a}$ & $2.0 \mathrm{a}$ & $1.05 \mathrm{a}$ & $6.46 \mathrm{a}$ \\
\hline Superficial & $20.8 \mathrm{a}$ & $1.03 \mathrm{a}$ & $2.8 \mathrm{a}$ & $362.5 \mathrm{a}$ & 444346 b & $53 \mathrm{~b}$ & $2.0 \mathrm{a}$ & $1.04 \mathrm{a}$ & $5.30 \mathrm{a}$ \\
\hline $\mathrm{F}$ & $37.42^{\mathrm{ns}}$ & $1.01^{\mathrm{ns}}$ & $0,57^{\mathrm{ns}}$ & $0,05^{\mathrm{ns}}$ & $46,15^{* *}$ & $17,81^{*}$ & $1,00^{\mathrm{ns}}$ & $0,79^{\mathrm{ns}}$ & $3,88^{\mathrm{ns}}$ \\
\hline \multicolumn{10}{|l|}{ Correctives (C) } \\
\hline SS & $25.9 \mathrm{a}$ & $0.86 \mathrm{~b}$ & $2.7 \mathrm{a}$ & $291.9 \mathrm{a}$ & 463194 a & $75 \mathrm{a}$ & $2.0 \mathrm{a}$ & $1.09 \mathrm{a}$ & $7.18 \mathrm{a}$ \\
\hline $\mathrm{W}$ & $22.2 \mathrm{ab}$ & $1.10 \mathrm{ab}$ & $2.7 \mathrm{a}$ & $426.9 \mathrm{a}$ & 515277 a & $53 \mathrm{c}$ & $2.0 \mathrm{a}$ & $1.21 \mathrm{a}$ & $6.25 \mathrm{ab}$ \\
\hline $\mathrm{C}$ & $17.7 \mathrm{~b}$ & $1.16 \mathrm{a}$ & $2.8 \mathrm{a}$ & $345.7 \mathrm{a}$ & 519443 a & $55 \mathrm{bc}$ & $2.0 \mathrm{a}$ & $1.01 \mathrm{a}$ & $4.32 \quad \mathrm{c}$ \\
\hline $\mathrm{LS}$ & $23.8 \mathrm{ab}$ & $0.94 \mathrm{ab}$ & $2.8 \mathrm{a}$ & $389.4 \mathrm{a}$ & 513548 a & $64 a b c$ & $2.0 \mathrm{a}$ & $0.86 \mathrm{a}$ & $5.98 \mathrm{abc}$ \\
\hline SSS & $21.6 \mathrm{ab}$ & $1.02 \mathrm{ab}$ & $2.7 \mathrm{a}$ & $419.8 \mathrm{a}$ & 503471 a & $75 \mathrm{a}$ & $2.0 \mathrm{a}$ & $1.16 \mathrm{a}$ & 5.22 bc \\
\hline CDL & $22.4 \mathrm{ab}$ & $1.09 \mathrm{ab}$ & $2.8 \mathrm{a}$ & $383.5 \mathrm{a}$ & 474999 a & $68 \mathrm{ab}$ & $2.0 \mathrm{a}$ & $1.03 \mathrm{a}$ & $6.40 \mathrm{ab}$ \\
\hline DL & $24.2 \mathrm{ab}$ & $0.87 \mathrm{ab}$ & $2.8 \mathrm{a}$ & $307.9 \mathrm{a}$ & $492360 \quad \mathrm{a}$ & $65 \mathrm{abc}$ & $2.0 \mathrm{a}$ & $0.94 \mathrm{a}$ & $5.80 \mathrm{abc}$ \\
\hline $\mathrm{F}$ & $2.49 *$ & $3.08 *$ & $1.62^{\mathrm{ns}}$ & $1.67^{\mathrm{ns}}$ & $0.43^{\mathrm{ns}}$ & $2.87 *$ & $0.64^{\mathrm{ns}}$ & $0.64^{\mathrm{n}}$ & $4.86^{* *}$ \\
\hline $\mathrm{A} \times \mathrm{C}$ & $0.66^{\text {ns }}$ & $2.76^{*}$ & $0.80^{\text {ns }}$ & $1.91^{\mathrm{ns}}$ & $0.43^{\mathrm{ns}}$ & $1.88^{\mathrm{ns}}$ & $1.53^{\mathrm{ns}}$ & $0.33^{\mathrm{ns}}$ & $1.00^{\mathrm{ns}}$ \\
\hline VC (\%) plot & 21 & 18 & 6 & 34 & 12 & 34 & 7 & 26 & 37 \\
\hline $\mathrm{VC}(\%)$ subplot & 20 & 19 & 4 & 31 & 19 & 23 & 15 & 29 & 20 \\
\hline
\end{tabular}

Averages followed by different letters in the columns differ among themselves. By the Tukey test at $5 \%\left({ }^{*}\right)$ and $1 \%(* *)$ probability. SS - Steel slag. W - Wollastonite. C control. LS - Ladle slag. SSS - Stainless steel slag. CDL - Calcined dolomitic lime. DL - Dolomitic lime. ns - not significant.

Table 6. Deployment of the interaction $x$ corrective for the enzyme Superoxide dismutase (SOD) (UI $\mu g$ proteín ${ }^{-1}$ ).

\begin{tabular}{ccc}
\hline \multirow{2}{*}{ Correctives } & \multicolumn{2}{c}{ Forms of application } \\
\cline { 2 - 3 } & Incorporated & Superficial \\
\hline SS & $0.90 \mathrm{aA}$ & $0.81 \mathrm{aC}$ \\
$\mathrm{W}$ & $0.97 \mathrm{aA}$ & $1.24 \mathrm{aB}$ \\
C & $0.99 \mathrm{bA}$ & $1.33 \mathrm{aA}$ \\
LS & $0.98 \mathrm{aA}$ & $0.91 \mathrm{aC}$ \\
SSS & $0.90 \mathrm{aA}$ & $1.13 \mathrm{aC}$ \\
CDL & $1.23 \mathrm{aA}$ & $0.95 \mathrm{aC}$ \\
DL & $0.89 \mathrm{aA}$ & $0.85 \mathrm{aC}$ \\
\hline
\end{tabular}

SS - Steel slag. W - Wollastonite. C - control. LS - Ladle slag. SSS - Stainless steel slag. CDL - Calcined dolomitic lime. DL - Dolomitic lime. ns - not significant. Capital letters correspond to the comparisons between the soil acidity correctives within the same mode of application. Lower case letters correspond to comparisons between the mode of application for the same soil acidity correction by the Tukey test at a level of $5 \%\left({ }^{*}\right)$ and $1 \%\left({ }^{* *}\right)$ probability.

soybean leaves, it did not inhibit the availability of $\mathrm{Ca}^{+2}, \mathrm{Mg}^{+2}$ and $\mathrm{Fe}^{+2}$ in the leaves. The number of plants per linear meter increased with the incorporation of soil acidity correctives in a no-till system (Rheinheimer et al, 2000). The number of pods per plant varied from 53 for incorporation to 78 for surface application (Table 4). This might have occurred because larger soybean plant populations are capable of producing more pods due to the greater number of ramifications, which determines higher knot production potential and, consequently, higher number of pods per plant (Mauad et al., 2010). Thus, this positively influenced the number of pods per plant considering the two analyzed factors.

There were satisfactory differences in productivity $\left(\mathrm{t} \mathrm{ha}^{-1}\right)$ with the application of the soil acidity correctives; steel slag led to the highest productivity, showing an average value of $7.18 \mathrm{t} \mathrm{ha}^{-1}$, while control had an average value of $4.32 \mathrm{t} \mathrm{ha}^{-1}$. Thus, the increased productivity observed in the present study is due to the residual effect of using steel slags as soil acidity corrective over time in the same area, which acted as a nutrient supplier to the soil and had a positive effect on productivity. It must be highlighted that productivity is also favored by other factors like genotypes of high productive potential and some environmental factors (Prado et al., 2001).

\section{Material and Methods}

\section{Description of the experimental site and soil}

The experiment was conducted between July 2019 and February 2020, under field conditions, at the College of Agronomic Sciences - São Paulo State University (Unesp), Botucatu, São Paulo State, Brazil $\left(22^{\circ} 50^{\prime} 19^{\prime \prime} \mathrm{S}\right.$ and $48^{\circ} 25^{\prime} 54^{\prime \prime}$ $\mathrm{W}$, at $738 \mathrm{~m}$ above sea level). The soil in that area was classified as Rhodic Hapludox (Soil Survey Staff, 2014), a dystrophic Red Latosol, according to the classification of Embrapa (2018).

The experiment was established in 2010 with the surface application and incorporation of the soil acidity corrective materials described on item 1.4. Still in 2010, before application of the corrective materials, the plots designated to receive treatments by incorporation were prepared by plowing with a reversible disc plough and harrowing with leveling disc harrow. Then, the corrective materials were manually applied on the soil surface and mechanically incorporated to $0-20 \mathrm{~m}$. After application, the no-tillage 
system was followed (Deus et al., 2020) for all treatments until 2013.

The liming was reapplied in 2013 and 2017, considering the soil chemical analysis for those years and the chemical characteristics of each corrective material; the dose was calculated to increase base saturation to $70 \%$. The corrective materials were applied on the soil surface and incorporated to $0-20 \mathrm{~cm}$ depth, following the proposed treatments. After each reapplication, the crops were conducted in a no-tillage system for all treatments.

In July 2019, chemical analysis was performed to characterize the soil at the $0-20 \mathrm{~cm}$ layer, following the methodology proposed by Raij et al. (2001).

\section{Treatments, experimental design and study development} Treatments consisted of two application methods (surface application and incorporation) of six soil acidity corrective materials, namely, steel slag (SS), ladle slag (LS), stainlesssteel slag (SSS), Wollastonite (W), Dolomitic lime (DL) and calcined dolomitic lime (CDL), in addition to one control treatment (C), to which no corrective material was applied. Experimental design was in randomized blocks with $42 \mathrm{~m}^{2}$ $(6 \mathrm{~m} \times 7 \mathrm{~m})$ subplots and four replicates. The major plots were compared for the application method, surface application or incorporation, while the sub-plots were compared for the applied corrective materials.

The plots that received treatments by incorporation were prepared with a grid of disc levelers; then, in October 2019, the correctives were manually applied on the soil surface and mechanically incorporated to $0-20 \mathrm{~m}$ with an intermediate degree grid. For the plots receiving surface treatments, the corrective materials were manually applied on the soil surface.

The used dose of each corrective was calculated to increase base saturation to $70 \%$, considering the result of the soil chemical analysis (Table 1) and the chemical composition of each corrective (Table 2). The chemical and physical characterization of corrective materials was carried out according to the Brazilian Legislation for Limestone (Alcarde, 2009).

After 60 days of application of the acidity correctives, soybeans of the cultivar 'TMG 7062 IPRO' were sown. The seeds were previously treated with the fungicide carboxin (carboxanilide) + thiram (dimethyldithiocarbamate) (9.6 g a.i. per $40 \mathrm{~kg}$ seeds) and the insecticide thiamethoxam (34 g a.i. per $40 \mathrm{~kg}$ seeds) and inoculated with liquid inoculum (5 $\mathrm{x}$ $10^{9} \mathrm{CFU}$ Bradyrhizobium japonicum $\mathrm{mL}^{-1}$ ).

Sowing was performed in November 2019, adopting $0.45 \mathrm{~cm}$ row spacing and 20 seeds $\mathrm{m}^{-1}$ sowing rate. Fertilization was conducted based on the recommendations for soybean by Raij et al. (1996) and on the chemical characteristics obtained in the soil analysis (Table 1), considering the average of all treatments, except the control treatment. Thus, $300 \mathrm{~kg} \mathrm{ha-}{ }^{1}$ of the formula 02-20-20 $\left(\mathrm{N}-\mathrm{P}_{2} \mathrm{O}_{5}-\mathrm{K}_{2} \mathrm{O}\right)$ were applied.

\section{Plant Measurements}

During full blooming (70 days after germination), analyses included leaf area $\left(\mathrm{cm}^{2}\right)$ measurement with a leaf area meter model LICOR LI-3000; fresh and dry masses of leaves and stems; relative water content (RWC) (Barr et al. 1962); electrolyte loss (EL) (Lafuente et al., 1991); pigment content (Hiscox \&amp; Israelstam, 1979); leaf levels of macro and micronutrients (Malavolta et al., 1997), Total Soluble Proteins (TSP) (Bradford, 1976) and silicon, and activity of the enzymes SOD (Giannopolitis and Ries, 1977), POD and CAT (Lock, 1963). For both variables, 2 to 5 leaves were collected from the middle third of the plant to perform all analyses.

At the end of the crop cycle, evaluations included number of pods per plant, number of grains per pod, silicon content in the grain, mass of 100 grains, and yield. Soybean harvest was manually performed 115 days after seedling emergence and consisted of collecting 2 lines of 2 meters per subplot; then, humidity was corrected to $13 \%$ and the yield was calculated as $\mathrm{t}^{-1}$ ha.

\section{Statistical analysis}

Data were subjected to Shapiro-Wilk test for normality. Results underwent analysis of variance and, when significant, were compared according to Tukey's test at 5\% probability. Statistical analysis was performed with the statistical software AgroEstat (Barbosa; Maldonado, 2015).

\section{Conclusions}

Application of correctives by incorporation favored soil aeration, which increased leaf biomass, stem weight, number of plants per linear meter, pigment content and, consequently, number of pods per plant.

The levels of micronutrients $(\mathrm{B}, \mathrm{Cu}, \mathrm{Fe}$ and $\mathrm{Zn}$ ) were within the adequate range for the crop, except manganese, which was toxic, triggering SOD activity (stress indicator) and promoting, especially for the control treatment, a decrease in the number of pods per plant and consequently lower soybean productivity.

\section{Funding}

To financial support from CNPq (National Councial for Scientific and Technological Development) (Grant no 134287/2019-3), for the awarded master's scholarship.

\section{Declaration of Competing Interest}

The authors have no conflicts of interest to declare.

\section{References}

Agarie S, Hanaoka N, Ueno O, Miyazaki A, Kubota F, Agata W, Kaufman PB (1998) Effects of silicon on tolerance to water deficit and heat stress inrice plants (Oryza sativa L.), monitored by electrolyte leakage. Plant Prod Science. 1:96-103.

Amaro ACE, Baron D, Ono EO, Rodrigues JD (2020) Physiological effects of strobilurin and carboxamides on plants: an overview. Acta Physiologiae Plantarum. 42:4.

Alcarde JC (2009) Official Methodology for Acidity Corrective Analysis. Porto Alegre-RS, 58p.

Ambrosano EJ, Tanaka RT, Mascarenhas HAA, Raij B van, Quaggio JÁ, Cantarella H (1997) Leguminosas e oleaginosas. In: RAIJ, B. van; Cantarela, H.; Quaggio, J. A.; Furlani, A. M. C. (Eds.). Recomendações de adubação e calagem para o Estado de São Paulo. 2 ed. Campinas: Instituto Agronômico. 2:187-202 (Boletim Técnico 100).

Barbosa JC, Maldonado Junior W (2015) AgroEstat - Sistema para Análises Estatísticas de Ensaios Agronômicos. Jaboticabal: UNESP. 
Barr HD and Weatherley PE (1962) A re-examination of the relative turgidity technique for estimating water deficit in leaves. Aust. J. Biol. Sci. p. 413-428.

Bradford MM (1976) A rapid and sensitive method for the microgram quantities of protein utilizing the principle of protein-dye-binding. Anal Biochem 72:248-254.

Companhia Nacional de Abastecimento (2019) Sexto levantamento de avaliação da safra 2019/2020. Brasília, p. 1-31.

Corrêa JC, Büll LT, Crusciol CAC, Morais MH (2009b) Alteração de atributos físicos em latossolo com aplicação superficial de escória de aciaria, lama cal, lodos de esgoto e calcário. Revista Brasileira de Ciência do Solo, 33: 263272.

DEUS, A. C. F.; BÜLL, L. T.; GUPPY, C. N.; SANTOS, S. M. C.; MOREIRA, L. L. Q. Effects of lime and steel slag application on soil fertility and soybean yield under a no till-system. Soil and Tillage Research, 196, 104422. (2020)

Deus ACF, Bertani RMA, Meirelles GC, Soares AAVL, Moreira LLQ, Büll LT, Fernandes DM (2019) The Comprehensive Utilization of Steel Slag in Agricultural Soils. In: Recovery and Utilization of Metallurgical Solid Waste. 10p.

Empresa Brasileira de Pesquisa Agropecuária - EMBRAPA (2018) Centro Nacional de Pesquisa de Solos. Sistema brasileiro de classificação de solos. Embrapa, E-book, Brasília

Gama JRFN, Carvalho EJM, Rodrigues TE, Valente MA (2007) Solos do estado do Pará. In: Cra Vom MS, Viégas IJM, Brasil EC (Ed.). Recomendações de adubação e calagem para o estado do Pará. Belém: Embrapa Amazônia Oriental, 1929.

Gill SS, Tuteja N (2010) Reactive oxygen species and antioxidant machinery in abiotic stress tolerance in crop plants. Plant Physiology and Biochemistry, 48:909-930.

Giannopolitis CN, Ries SK (1977) Superóxido dismutases. I. Occurrence in higher plants. Plant Physiology 59:309-314.

Heenan DP, Campbel OG (1980) Growth, yield componets and seed composition of two soy-bean cultivars affected by manganese supply - Australian Journal of Agricultural Research. 31: $471-476$.

HiscoX JD, Israelstam GF (1979) A method for the extraction of chlorophyll from leaf tissue without maceration. Canadian Journal of Botany. 57:1132-1334.

Imtiaz M, Rizwan MS, Mushtaq MA, Ashraf M, Shahzad, SM, Yousaf B, Saeed DA, Rizwan M, Nawaz A, Mehmood S, Tu S (2016) Silicon occurrence, uptake, transport and mechanisms of heavy metals, minerals and salinity enhanced tolerance in plants with future prospects: A review. Journal of Environmental Management. 183(3):521- 529.

Korndörfer GH, Pereira HS, Nolla A (2004) Análise de silício no solo, planta e fertilizante. Uberlândia: GPSi 50p. (Boletim Técnico $\mathrm{n}^{\circ}$ 02).

Lafuente MT, Belver A, Guye MG, Salveit ME (1991) Effect of the temperature conditioning on chilling injury of cucumber cotyledons. Plant Physiology. 95:443-449.
Lock H (1963) Catalase. In: Bergmeyer HU (ed) Methods of enzymatic analysis, vol 2. Verlag Chemie, Weinheim/Bergstr. pp 885-894.

Lopes AS, Silva MC, Guimarães GLR (1991) Correção da acidez do solo. São Paulo: ANDA. 22 p. (Boletim Técnico 1).

Malavolta E, Vitti GC, Oliveira AS (1997) Avaliação do estado nutricional das plantas: princípios e aplicações. 2.ed. ver. e atual. Piracicaba: Potafos, 2:319.

Martins CM, Martins SCS, Borges WL (2017) Correção da acidez, adubação e fixação bológica. Embrapa AmapáCapítulo em livro científico (ALICE).

Mauad M, Silva TLB, Neto AIA, Abreu VG (2010) Influência da densidade de semeadura sobre características agronômicas na cultura da soja. Dourados - MS. 3(9):175181.

Pauletti V, Pierri LD, Ranzan T, Barth G, Motta ACV (2014) Efeitos em longo prazo da aplicação de gesso e calcário no sistema de plantio direto. Revista Brasileira de Ciência do Solo. 38(2): 495-505.

Prado RM, Fernandes FM, Natale W (2001) Uso agrícola da escória de siderurgia no Brasil - Estudos na cultura da cana-de-açúcar. Jaboticabal, Funep, 68.

Pulz AL, Crusciol CAC, Lemos LB, Soratto RP (2008) Influência de silicato e calcário na nutrição, produtividade e qualidade de batata sob deficiência hídrica. Revista Brasileira de Ciência do Solo. 32:1651-1659.

Qi J, Song CP, Wang B, Zhou J, Kangasjarvi J, Zhu JK, Gong Z (2018) Reactive oxygen species signaling and stomatal movement in plant responses to drought stress and pathogen attack. J Integr Plant Biol. 60:805-826.

Raij B. van, Cantarela H, Quaggio JÁ, Furlani AMC (1997) Recomendações de adubação e calagem para o Estado de São Paulo. Campinas: IAC, 2:285 (Boletim Técnico 100).

Rheinheimer DS, Santos EJS, Kaminski J, Bortoluzzi EC, Gatiboni LC (2000) Alterações de atributos do solo pela calagem superficial e incorporada a partir de pastagem natural. Revista Brasileira de Ciência do Solo, Viçosa, 24:797-805.

Rosolem CA, Bessa MA, Amaral PG, Pereira HFM (1992) Manganês no solo: sua avaliação e toxidez de manganês em soja. Pesquisa Agropecuaria Brasileira, Brasília. 27(2):277-285.

Silva MA, Santos CM, Vitorino HS, Rhein AFL (2014) Pigmentos fotossintéticos e índice spad como descritores de intensidade do estresse por deficiência hídrica em cana-de-açúcar. Bioscience Journal, Uberlândia. 30(1):173181.

Soil Survey Staff (2014) Keys to Soil Taxonomy, twelfth ed. USDA- United States Department of Agriculture. Vargas JPR, Santos DR, Bastos MC, Schaefer G, Parisi P.B.

Souza MLC, Starling CDSAZ, Machuca LMR, Zuñiga EA, Galvão ÍM, de Jesus Guimarães J, Broetto, F (2020) Biochemical parameters and physiological changes in maize plants submitted to water deficiency. SN Applied Sciences, 2(3), 1-9. 